\title{
Class II UvrA protein Ecm16 requires ATPase activity to render
}

\section{resistance against echinomycin}

\section{Summary}

Bacteria use various strategies to become antibiotic resistant. The molecular details of these strategies are not fully understood. We can increase our understanding by investigating the same strategies found in antibiotic-producing bacteria. In this work, we characterize the self-resistance protein Ecm 16 encoded by echinomycin-producing bacteria. Ecm16 is a structural homolog of the Nucleotide Excision Repair (NER) protein UvrA. Expression of ecm 16 in the heterologous system Escherichia coli was sufficient to render resistance against echinomycin. Ecm16 preferentially binds double-stranded DNA over singlestranded DNA and is likely to primarily interact with the backbone of DNA using a nucleotideindependent binding mode. Ecm16's binding affinity for DNA increased significantly when the DNA is intercalated with echinomycin. Ecm 16 can repair echinomycin-induced DNA damage independently of NER. Like UvrA, Ecm16 has ATPase activity and this activity is essential for Ecm16's ability to render echinomycin resistance. Notably, UvrA and Ecm16 were unable to complement each other's function. Increasing the cellular levels of UvrA in E. coli was insufficient to render echinomycin resistance. Similarly, Ecm16 was unable to repair DNA damage that is specific to UvrA. Together, our findings identify new mechanistic details of how a refurbished DNA repair protein Ecm 16 can specifically render resistance to the DNA intercalator echinomycin. Our results, together with past observations, suggest a model where Ecm16 recognizes double helix distortions caused by echinomycin and repairs the problem independently of NER.

\section{Key Words}

37 Ecm16, Echinomycin, UvrA, Nucleotide Excision Repair, DNA intercalator, Antibiotic resistance. 


\section{(a) INTRODUCTION}

The current crisis with antibiotic resistance has become one of the biggest public health challenges of our time (CDC). Bacteria can acquire antibiotic resistance through various mechanisms that include the upregulation of efflux pumps, modification of antibiotics, and modification and protection of the antibiotic target. Notably, many of these antibiotic resistance mechanisms have also been found in bacteria that are themselves producers of antibiotics, which are utilized for self-protection $(1,2)$. Some genes involved in these antibiotic resistance mechanisms have been proposed to originate from antibiotic-producing bacteria shared with pathogenic bacteria through transformation, transduction, or conjugation (3-6). This potential sharing of genetic information highlights the importance of identifying the mechanistic details of self-resistance found in antibiotic-producing bacteria.

About $80 \%$ of our known antibiotics are produced by Streptomyces spp. (7). One such antibiotic produced by Streptomyces is echinomycin, the first identified DNA bis-intercalator (8). Echinomycin, a member of the quinomycin family of antibiotics, contains two planar quinoxaline chromophores connected by a cyclic octadepsipeptide (9-11) (Figure 1A). Quinomycins have been shown to possess antimicrobial, antiviral, and antitumor activities (12-16). Echinomycin was originally discovered in Streptomyces echinatus but has since been found to be produced by several species of Streptomyces (17, 18). In one of these species, Streptomyces lasolacidi (formerly known as S. lasaliensis), the echinomycin biosynthetic gene cluster lies within a 36 Kilobase region of a 520 Kilobase giant linear plasmid (19-21). This gene cluster consists of eight genes involved in quinoxaline-2-carboxylic acid synthesis, five genes for octadepsipeptide backbone synthesis (21), and five genes that encode proteins proposed to have regulatory or unknown functions (18). One of the genes of unverified function, ecm 16, encodes a homolog of the prokaryotic nucleotide excision repair (NER) protein UvrA, which has been proposed to serve as a self-resistance protein against echinomycin (21). Interestingly, other DNA intercalator drugs like daunorubicin and triostin A also include a UvrA-homolog encoding gene in their biosynthetic clusters: $\operatorname{drr} C$ and $\operatorname{trs} M(1,21-25)$. DrrC has been shown to render self-protection in Streptomyces peucetius against daunorubicin $(26,27)$. However, mechanistic understanding of how DrrC renders resistance against daunorubicin remains limited.

UvrA is part of the nucleotide excision repair (NER) system responsible for repairing diverse types of DNA damage in bacteria, including pyrimidine dimers $(28,29)$, unpaired $\mathrm{T}$ and $\mathrm{G}$ residues (30), backbone modifications such as single nucleotide gaps and nicks (26, 31-33), and damage conferred by 
anthramycin $(31,34,35)$, cholesterol adducts (36), and fluorescein (33). The NER protein involved in recognizing DNA damage is UvrA, a dimeric protein with a total of four ATP-binding sites, two UvrBbinding domains, and a single DNA binding groove (37-41). ATPase activity conferred by the ATPbinding domains is necessary for UvrA's interaction with DNA, dissociation of dimer into monomers, and interaction with $\operatorname{UvBB}(41,42)$. Two models have been proposed regarding detection of damaged DNA: (1) UvrA scans DNA alone until it detects a lesion, at which point it stalls and complexes with UvrB (43) and (2) a UvrA2-UvrB 2 complex searches and locates damaged DNA (44, 45). In either model, UvrA is the first protein of the NER system to bind DNA and the one responsible for promoting conformational changes of DNA and UvrB for both to bind to each other (46). Defining the molecular mechanism used by UvrA to recognize the wide range of DNA damage types has remained elusive in the field.

In addition to the canonical UvrA, several bacterial phyla (including Actinobacteria, Firmicutes, Bacteroidetes and Proteobacteria) also express a class II UvrA (47). The UvrA homologs found in Streptomyces that produce DNA intercalator drugs are class II UvrA (referred here as UvrA2) $(1,48)$. The specific functions of UvrA2 proteins in various bacterial species remain unclear. For instance, in $D$. radiodurans, expression of $u v r A$ and $u v r A 2$ gene is upregulated following ionizing radiation (49). However, deletion of the $u v r A 2$ gene had no effect on the cell's UV sensitivity (50). In Xanthomonas axonopodis and Pseudomonas putida, the double knockout $\triangle u v r A \triangle u v r A 2$ displayed slightly higher sensitivity to high UV radiation compared to the single knockout $\triangle u v r A$ suggesting that UvrA2 can contribute, although at a minor level, to the repair of UV-induced DNA damage (51). In P. putida, UvrA2 was proposed to also be involved in mutagenesis mechanisms during stationary growth phase (52). Overall, our knowledge about the specific roles that class II UvrA proteins play in bacteria and whether they can substitute the activity of the canonical UvrA remain limited.

In this study, we present the in vivo and in vitro characterization of Ecm16, a UvrA2 protein from Streptomyces lasalocidi $(1,48)$. We demonstrate in vivo that the expression of ecm 16 is sufficient to render the echinomycin-sensitive $E$. coli resistant to relatively high levels of echinomycin $(20 \mu \mathrm{M})$. In vitro, we showed that, unlike UvrA, Ecm16 preferentially binds echinomycin-containing doublestranded DNA. Similar to UvrA, Ecm 16 can hydrolyze ATP suggesting that UvrA2 type proteins require ATPase activity for detecting/repairing DNA damage. Furthermore, Ecm16's drug resistance activity does not require any of the other components of the classical NER pathway. Ecm 16 was unable to complement an E. coli uvrA knockout strain recovering from UV-induced DNA damage. Collectively, 
101 our work provides new insights into how class II UvrA proteins catalyze drug resistance independently 102 of the evolutionarily related protein UvrA.

\section{(b) RESULTS}

105 Expression of ecm 16 provides resistance against echinomycin. Although previously proposed, there 106 is no experimental data in the literature confirming that Ecm16 can render resistance against 107 echinomycin (21). To provide this evidence and characterize Ecm16, we used E. coli (K12) cells as a 108 heterologous host system to express ecm16. The natively echinomycin-sensitive E. coli cells were 109 transformed with a low-copy vector encoding ecm 16 under the arabinose inducible promoter $110[\mathrm{p}(\mathrm{ecm} 16)]$. In the absence of echinomycin, E. coli cells with vector-control-only (VCO) reached 111 saturation $\left(\mathrm{OD}_{600 \mathrm{~nm}} \sim 1.0\right)$ within a $6 \mathrm{~h}$ growth period (Figure $\left.1 \mathrm{~B}\right)$. The same VCO cells grown in the 112 presence of $1 \mu \mathrm{M}$ echinomycin only reached $\sim 0.35 \mathrm{OD}_{600 \mathrm{~nm}}$ within the same $6 \mathrm{~h}$ period. Almost no 113 detectable growth was observed for VCO cells at echinomycin concentration of $10 \mu \mathrm{M}$ or higher. In 114 contrast, E. coli cells expressing ecm 16 reached equivalent maximal densities when grown in the 115 presence or in the absence of supplemented echinomycin. Using growth curve analyses, we determined 116 the effect of ecm 16 expression on doubling rates (Figure 1C). In the absence of echinomycin, E. coli 117 with or without expression of ecm 16 were able to double every $\sim 0.54$ h under our growth conditions. 118 However, in the presence of echinomycin, the doubling rate of VCO cells increased more than 7-fold.

119 Remarkably, cells expressing ecm 16 were able to maintain their normal doubling rate up to levels of 20 $120 \mu \mathrm{M}$ echinomycin.

122 E. coli adopt filamentous shapes in response to a variety of stressful environments, including DNA 123 damage and exposure to antibiotics (53-56). To determine whether Ecm16 can prevent cellular 124 filamentation, we analyzed the cell length of $E$. coli after exposure to echinomycin. The average cell 125 length of $E$. coli was determined to be $\sim 2.5 \mu \mathrm{m}$ when grown in the absence of any drug. However, the 126 average cell length increased six-fold $(\sim 14.9 \mu \mathrm{m})$ when grown in the presence of echinomycin $(5 \mu \mathrm{M})$

127 (Figure 2). Exposure to echinomycin resulted in cells with broad cell length distribution and maximum 128 lengths reaching up to $\sim 54 \mu \mathrm{m}$. We observed that the expression of ecm 16 alone in the absence of any 129 echinomycin, resulted in an average cell length that was longer $(\sim 3.8 \mu \mathrm{m})$ compared to the $\mathrm{VCO}(\sim 2.5$ $130 \mu \mathrm{m})$. However, when echinomycin was supplemented to cells expressing ecm 16, cell length was not 131 altered compared to the no echinomycin control treatment. In summary, our in vivo analyses revealed 
132 that the expression of ecm 16 in E. coli cells results in protection against the toxicity caused by

133 echinomycin exposure.

\section{Ecm16 binds preferentially to double-stranded DNA-echinomycin}

136 We next investigated how the local DNA structure influences Ecm16's ability to recognize its substrate.

137 The NER UvrA from E. coli and Mycobacterium tuberculosis has been shown to exhibit stronger

138 affinity for single-stranded DNA (ssDNA) versus double-stranded DNA (dsDNA) (57, 58). Using

139 electrophoretic mobility shift assay, we characterized the DNA binding activity of purified recombinant

140 Ecm16 to various DNA substrates (Figure 3A). Our data revealed that unlike UvrA, Ecm16 displays

141 stronger binding affinity to dsDNA compared to ssDNA suggesting a potential mechanistic difference in

142 damage recognition and/or repair (Figure 3B). The substrate affinity of Ecm16 was further increased

143 when dsDNA was combined with echinomycin (Figure 3AB). Given that echinomycin intercalates DNA

144 with a preference for CpG sites $(10,59)$, we tested whether Ecm 16 displays stronger affinity for specific

145 DNA sequences. To determine whether Ecm16 displayed any DNA preference, we analyzed different

146 combinations of DNA sequences using electrophoretic mobility shift assays where the levels of Ecm 16

147 were titrated. We varied the percent of GC and AT content of the DNA substrate (Figure 3C). Our

148 results revealed no significant differences in Ecm16's substrate binding with varying GC/AT content,

149 suggesting that Ecm16 primarily interacts with the backbone, and not the bases, of DNA. These data

150 indicate that Ecm 16 has substrate specificity and/or higher binding affinity for dsDNA-echinomycin and

151 binds DNA in a nucleotide-independent mode. Collectively, these data suggest that Ecm16 does not

152 explicitly bind regions prone to echinomycin binding but instead Ecm16 may scan dsDNA to detect

153 lesions caused by echinomycin.

\section{Ecm16 displays ATPase activity that is essential for echinomycin resistance}

156 The ATPase activity of UvrA is required for UvrA's ability to recognize DNA damage and initiate the 157 repair mechanism $(42,60)$. Ecm 16, like other UvrA homolog proteins, has high conservation of the 158 amino acids involved in ATP binding/hydrolysis, including those found in Walker A, Walker B, and the 159 alpha-helical ABC signature sequence (Supplemental Figure 1). To determine whether Ecm16 displays 160 ATPase activity and whether this activity is involved in protection against echinomycin, we first 161 characterized Ecm16's ability to hydrolyze ATP in vitro. To do that, we used a coupled assay in which 162 the substrate, 2-amino-6-mercapto-7-methylpurine riboside, is enzymatically converted to ribose 1- 
163 phosphate and 2-amino-6-mercapto-7-methylpurine by purine nucleoside phosphorylase in the presence 164 of inorganic phosphate (Figure 4A). Ecm16 shows basal level ATP hydrolysis activity in the absence of 165 any substrate, a characteristic which is also observed in UvrA (57). The addition of dsDNA increased 166 Ecm16's ATPase specific activity 10-fold, while addition of echinomycin-dsDNA complex increased 167 the ATPase activity 200 -fold (Figure 4). We next determined whether the observed ATPase activity of 168 Ecm16 was involved in Ecm16's ability to render echinomycin resistance in vivo. To do that, we 169 targeted a conserved residue (Lys526) in UvrA-type proteins that has been shown to be essential for 170 discriminating between native and damaged DNA (61-64). To determine whether Ecm16 requires its 171 ATPase activity in vivo, we engineered an Ecm16 variant with the conserved residue Lys526 changed to 172 an alanine and analyzed the ability of an E. coli strain expressing this variant $\left(\mathrm{Ecm} 16^{\mathrm{K} 526 \mathrm{~A}}\right)$ to confer 173 echinomycin resistance. Our data revealed that $E$. coli cells exclusively expressing the variant $174 \mathrm{Ecm} 16^{\mathrm{K} 526 \mathrm{~A}}$ failed to rescue cells from echinomycin toxicity (Figure 4B). These data suggest that Ecm 16 175 may use ATP hydrolysis for scanning DNA for damage recognition and/or repair.

176 Ecm16's echinomycin resistance activity does not require components of the NER system. Based 177 on similarities between Ecm16 and UvrA, we examined whether Ecm16's mechanism of protective 178 action against echinomycin resembles the activity of the DNA repair protein UvrA. In E. coli, UvrA or $179 \mathrm{UvrA}_{2}-\mathrm{UvrB}_{2}$ detects DNA damage and recruits the rest of the NER system (UvrB/C/D) (65-68). To 180 address the possibility that Ecm16's ability to render cells echinomycin resistance requires the function 181 of NER components, we analyzed E. coli strains with knockouts of each individual component ( $u v r A$, $182 u v r B, u v r C$, and $u v r D$; Keio Collection) (69) (Figure 5A). To each of these strains, we transformed the 183 replicating plasmid encoding ecm 16 or $\mathrm{VCO}$. We tested the ability of these strains to grow in the 184 presence of echinomycin concentrations that were tolerated by cells expressing ecm 16. Our growth 185 analyses revealed that cells encoding the NER system and cells without components of the NER system 186 displayed similar doubling rates when grown in the presence of echinomycin. Ecm16 was able to 187 provide the same level of echinomycin resistance in the absence of NER.

\section{Ecm16 and UvrA cannot complement each other's function.}

190 In E. coli, the activity of UvrA is essential for repairing various types of DNA damage including 191 thymine dimers resulting from exposure to UV radiation (70). To determine whether Ecm16 can complement UvrA's activity, we examined the ability of various strains to recover from UV radiation by 
performing Colony Forming Unit (CFU) assays (Figure 5B). E. coli cells with their native uvrA gene and VCO can effectively recover from $10 \mathrm{~J} / \mathrm{m}^{2}$ of UV radiation exposure as evidenced by the similar number of CFUs compared to the no-radiation control. However, the cell's ability to recover from UV radiation is significantly reduced when $E$. coli's native $u v r A$ gene is knocked out. Once $u v r A$ was expressed in trans from a replicating plasmid under the control of the arabinose inducible promoter, the ability to repair DNA damage was fully recovered. These data are in accordance with previous analyses of $u v r A$ knockout strains (71). However, when the gene encoding for Ecm16 was expressed in trans from the same replicating plasmid controlled by the arabinose promoter, E. coli cells were unable to recover from UV radiation. The number of CFUs of the strain expressing ecm 16 was as diminished as the CFUs observed on the $u v r A$ knock out strain. The same trend of UV resistance was also observed among the $E$. coli strains when lower levels of radiation $\left(5 \mathrm{~J} / \mathrm{m}^{2}\right)$ were used. The inability of Ecm 16 to complement a $u v r A$ knockout suggests that Ecm16 is unable to recognize thymine dimers and/or recruit the rest of the NER system for proper DNA repair.

Given that E. coli $\mathrm{K} 12$ cells display sensitivity to echinomycin suggested that UvrA is unable to protect from echinomycin toxicity. To determine whether increasing the cellular levels of UvrA would result in protection against echinomycin, we constructed an E. coli strain with two copies of $u v r A$ : its native copy and a second copy expressed in trans from a replicating plasmid (same vector used for ecm 16 expression). Cells expressing $u v r A$ from the inducible promoter grown in the presence of echinomycin display the same growth defect as the empty vector control (Supplemental Figure 2). These results confirm that UvrA and Ecm16 cannot complement each other's function due to either differences in damage detection and/or repair.

\section{(c) DISCUSSION}

In this study, we provide in vivo and in vitro characterization of Ecm16, a class II UvrA protein. Our data demonstrate that expression of ecm16 is sufficient to confer echinomycin resistance to an otherwise echinomycin sensitive bacterium, E. coli K12. We show that ATP hydrolysis of Ecm 16 is required for its ability to render resistance. Furthermore, Ecm16 was able to confer echinomycin resistance to host cells which are deficient in UvrA, UvrB, UvrC, or UvrD, indicating that Ecm16 does not depend on the NER machinery for its function. Finally, our data reveal that despite the sequence similarity between UvrA and Ecm 16, they are unable to complement each other's function. Collectively, 
our data expand our current understanding of the various mechanism that UvrA2 proteins utilize for their function.

Our work provides further insights into the potential mechanism used by Ecm16 to render resistance from echinomycin toxicity. The fact that Ecm16 binds DNA-echinomycin specifically implies that Ecm16's mode of action relies on Ecm16 binding DNA, and not detoxifying the cell by sequestering echinomycin away from DNA. Furthermore, UvrA recognizes DNA lesions and promotes the recruitment of the rest of the NER system to excise the damaged DNA. However, Ecm 16 retained its ability to render echinomycin resistance in the absence of any of the NER proteins. This observation posits two potential models where Ecm16 can either work with other housekeeping proteins found in $E$. coli or Ecm16 can work alone. The former model is plausible given that UvrA has been shown to work collaboratively with non-NER proteins $(72,73)$. In the scenario where the latter model is correct, we envision Ecm16 to use ATP hydrolysis to unwind, stretch, or compress DNA thereby dislodging echinomycin from DNA. UvrA has been proposed to subject DNA to a 'stress test' where UvrA unwinds and stretches-compresses DNA during the detection of damage (74). Ecm16 could be using a version of this 'stress test' mechanism but in doing that it would potentially release the echinomycin bound and thus repair the damage of DNA. We are currently testing between these two potential models. damage, conclusively addressing the mechanism of recognition remains a major gap in our knowledge in both bacterial and eukaryotic NER systems. We propose that the understanding of the mechanism of substrate recognition by Ecm16 can provide insights into how the NER system recognizes its substrates.

244 This is particularly the case given that UvrA and Ecm16 were unable to promote each other's function. Ecm16 and UvrA may be able to detect different types of distortions of the DNA double helix. UvrA has been proposed to distinguish between native and damaged DNA by sensing changes in various properties of DNA (structural, electrostatic, dynamics, stability, flexibility) (46). Our data revealed that UvrA is unable to repair echinomycin-induced damage possibly because the distortions of DNA caused by echinomycin are not recognized by UvrA or the NER system is unable to repair the damage. Figuring out details of either mechanism would advance our understanding of NER and DNA damage recognition and repair. Furthermore, UvrA and Ecm16 seem to also have different preferences between ssDNA and dsDNA that can potentially illustrate differences in damage recognition. Further work on Ecm16 will advance not only our understanding of how antibiotic-producer bacteria become antibiotic resistant but also advance understanding of the conserved NER system. 


\section{(d) EXPERIMENTAL PROCEDURES}

Bacterial growth conditions. E. coli strains were grown in Luria Bertani broth (LB) (Fisher BioReagents, NJ, U.S.A.). All cultures grown in liquid media were grown at $37^{\circ} \mathrm{C}$ with orbital shaking at $200 \mathrm{rpm}$.

Strains cultured on solid media were plated on LB agar (Fisher BioReagents, NJ, U.S.A.) and incubated at $37^{\circ} \mathrm{C}$. Ampicillin (amp) resistant strains were grown with $50 \mu \mathrm{g}$ amp/mL liquid media (Ampicillin sodium salt prepared in $\mathrm{H}_{2} \mathrm{O}$, Amresco, Ohio, U.S.A.) and $100 \mu \mathrm{g}$ amp/mL solid media. Kanamycin (kan) resistant strains were treated with $30 \mu \mathrm{g} \mathrm{kan} / \mathrm{mL}$ for liquid media (kanamycin sulfate prepared in $\mathrm{H}_{2} \mathrm{O}$, IBI Scientific, NJ. U.S.A.), and $50 \mu \mathrm{g} \mathrm{kan} / \mathrm{mL}$ for solid media. For induction, 0.2\% L-(+)Arabinose (Alfa Aesar, G.B.) was added to either liquid or solid media. Strains grown with echinomycin were treated with $1 \mu \mathrm{M}-20 \mu \mathrm{M}$ of echinomycin diluted in $\mathrm{H}_{2} \mathrm{O}$ from a $908 \mu \mathrm{M}$ echinomycin (Sigma, U.S.A.) solution prepared in methanol (Fisher Chemical, NJ, U.S.A.). All strains and primers used for this study are listed in Supplemental Tables S1 and S2.

Growth analyses. Cultures were grown in liquid media with ampicillin overnight from frozen stocks, incubated at $37^{\circ} \mathrm{C}$ and $200 \mathrm{rpm}$. Saturated cultures were diluted with fresh medium and induced with a $0.2 \%$ arabinose solution for 60 minutes and used to inoculate $2 \mathrm{~mL}$ duplicate replicate samples at a starting optical density of $0.02 \mathrm{OD}_{600}$ in $13 \mathrm{~mm}$ glass tubes. Cultures were grown in rich liquid media (LB), with Ampicillin and $0.2 \%$ Arabinose, incubated at $37^{\circ} \mathrm{C}$ and $200 \mathrm{rpm}$. Optical density readings were taken every 30 minutes for 6 hours using Thermo UV-Vis Spectrophotometer. Maximum growth in echinomycin was determined by evaluating serial dilutions of echinomycin in $\mathrm{H}_{2} \mathrm{O}$ when added to LB media inoculated with K12 E. coli culture, using $1 \mu \mathrm{M}$ to $20 \mu \mathrm{M}$ ech. K12/pBAD (vector control) and $\mathrm{K} 12 / \mathrm{pBAD}$-ecm 16 were grown overnight from frozen stocks at $37^{\circ} \mathrm{C}$ and $200 \mathrm{rpm}$, and prepared as in growth curves. Endpoint readings were taken after 6 hours of incubation. Imaging. K12 strains were grown from frozen stocks and used to inoculate $3 \mathrm{~mL}$ of LB/Amp/0.2\% arabinose to $0.2 \mathrm{OD}_{600}$. Cells were induced with $0.2 \%$ arabinose 30 minutes prior to dilution. Following inoculation, cultures were treated with $5 \mu \mathrm{M}$ echinomycin and grown for 5 hours. Cultures were spotted on $0.2 \%$ agarose (Ultrapure, Invitrogen, Spain) discs, and visualized with phase contrast microscopy using Zeiss Axio Observer 2.1 inverted microscope with a Plan-Apochromat 100×/1.40 Oil Ph3 M27 (WD=0.17 mm) objective, AxioCam 506 mono camera and ZEN software. Cell size was calculated using ImageJ/FIJI with MicrobeJ (75-78) 
285 Colony Forming Units. Cultures were grown overnight incubated at $37^{\circ} \mathrm{C}$ and $200 \mathrm{rpm}$ in liquid media 286 with ampicillin and used to inoculate samples to $0.3 \mathrm{OD}_{600}$ the following day. $0.2 \%$ arabinose was added 287 to each sample and cells were incubated for 2 hours. Cells were then serially diluted by factors of 10 and $2885 \mu \mathrm{L}$ of cultures were spotted on LB/Ampicillin plates with $0.2 \%$ Arabinose. Plates were exposed to 289 ultraviolet radiation (nm) at $5 \mathrm{~J} / \mathrm{m}^{2}$ or $10 \mathrm{~J} / \mathrm{m}^{2}$ or no $\mathrm{UV}$ as a negative control.

290 Purification of Ecm16. Recombinant proteins were expressed by transforming E. coli BL21 (de3)

291 (Novagen, Merck Millipore) host strains with the recombinant pET28a constructs encoding Ecm16 wild292 type. Cells were cultured at $37^{\circ} \mathrm{C}$ in $5 \mathrm{ml}$ of LB medium supplemented with kanamycin to an optical 293 density of $\sim 0.6-0.8$ at $600 \mathrm{~nm}$. Protein expression was performed by inducing the cells with $0.1 \mathrm{mM}$ 294 isopropyl- $\beta$-D-thiogalactoside, and growth was continued for a further $16 \mathrm{~h}$ at $18^{\circ} \mathrm{C}$. Cell pellet was 295 resuspended in lysis buffer containing 50 mM HEPES pH 7.5, $200 \mathrm{mM} \mathrm{NaCl}, 10 \%$ glycerol, $10 \mathrm{mM}$ Imidazole, $1 \mathrm{mM}$ Phenylmethylsulphonyl fluoride (PMSF), $10 \mu \mathrm{g} / \mathrm{ml}$ DNase and $10 \mathrm{mM} \mathrm{MgCl}$. Cells were disrupted using using sonication (Branson Ultrasonics) and cell debris was discarded by centrifugation at $15,000 \mathrm{~g}$ for 45 minutes at $4{ }^{\circ} \mathrm{C}$. Cleared cell lysate was applied on $5 \mathrm{ml}$ His-Trap Crude column (GE Healthcare) equilibrated with loading buffer (50 mM HEPES, pH, 7.5 and $200 \mathrm{mM} \mathrm{NaCl}$ ). The protein was eluted with a step gradient of imidazole $(250 \mathrm{mM})$ using elution buffer $(50 \mathrm{mM}$ HEPES $\mathrm{pH}$ 7.5, $200 \mathrm{mM} \mathrm{NaCl}, 500 \mathrm{mM}$ Imidazole). Ecm16 eluted from the nickel column was diluted up to 10fold using dilution buffer ( $50 \mathrm{mM}$ HEPES pH 7.5, $50 \mathrm{mM} \mathrm{NaCl})$. The diluted protein was applied to $5 \mathrm{ml}$ Hi-Trap Q HP anion-exchange column (GE Healthcare). Protein was eluted with 5 column volumes (CV) linear $\mathrm{NaCl}$ gradient from $50 \mathrm{mM}$ to $500 \mathrm{mM}$ concentration. The protein was concentrated up to 4-6 $\mathrm{mg}$ $\mathrm{ml}^{-1}$ and gel filtration was performed on Superdex 200 10/300 GL (GE Healthcare) equilibrated with storage buffer (50 mM HEPES pH 7.5, $50 \mathrm{mM} \mathrm{NaCl}$ ). The eluted protein sample was concentrated up to $8-10 \mathrm{mg} \mathrm{ml}^{-1}$, shock-frozen in liquid nitrogen and stored at $-80^{\circ} \mathrm{C}$. Electrophoretic mobility shift assay. Stock solutions of echinomycin (908 $\mu \mathrm{M})$ (Cayman Chemical) were prepared by dissolving the echinomycin powder in 100\% methanol. DNA-echinomycin complex was allowed to form by incubating 1: 1.1 molar ratio of DNA:echinomycin for 15 min at room temperature. DNA-echinomycin was incubated at room temperature for 20 min with Ecm 16 protein at concentrations ranging from 100 to $300 \mathrm{nM}$ in $10 \mu$ l reactions containing binding buffer $(50 \mathrm{mM}$

313 HEPES pH 7.5, $50 \mathrm{mM} \mathrm{NaCl}$ ). The reaction was terminated by adding 4\% sucrose solution. The protein314 DNA complex was electrophoretically separated at $4^{\circ} \mathrm{C}$ on $6 \%$ native polyacrylamide TBE gel 315 (Invitrogen) at $75 \mathrm{~V} / \mathrm{cm}$. The gel was stained for $10 \mathrm{~min}$ in $1 \mathrm{x}$ TBE buffer containing $5 \mu \mathrm{L}$ of SYBR 
316 gold nucleic acid gel stain (Invitrogen). The band intensity corresponding to the free DNA and protein-

317 DNA were visualized by ultraviolet transillumination complex and the bands were quantified using

318 ImageJ software (79).

319 ATPase activity assay. Adenosine triphosphate (ATP) was dissolved in storage buffer (50 mM HEPES

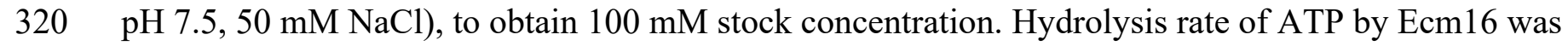

321 measured using a coupled enzyme assay where the substrate 2-amino-6-mercapto-7-methylpurine

322 riboside (MESG) is enzymatically converted to ribose 1-phosphate and 2-amino-6-mercapto-7-

323 methylpurine by purine nucleoside phosphorylase (PNP) in presence of inorganic phosphate (Pi). The

324 reaction mixture $(100 \mu \mathrm{L})$ contained $50 \mathrm{mM}$ HEPES pH 7.5, $50 \mathrm{mM} \mathrm{NaCl}, 0.5 \mathrm{mg} / \mathrm{ml} \mathrm{BSA}, 10 \%$

325 glycerol, $10 \mathrm{mM} \mathrm{MgCl}_{2}, 1 \mathrm{mM}$ ATP, $0.2 \mathrm{mM} \mathrm{MESG}, 1 \mathrm{x}$ reaction buffer $(50 \mathrm{mM}$ Tris $\mathrm{HCl} \mathrm{pH} 7.5,10$

$326 \mathrm{mM} \mathrm{MgCl2}, 0.1 \mathrm{mM}$ sodium azide), $1 \mathrm{U} / \mathrm{ml} \mathrm{PNP}$ and $0.5 \mu \mathrm{M}$ Ecm16 protein. The Reaction was carried

327 by monitoring the increase in absorbance at $360 \mathrm{~nm}$ over a 60 -minute period. The rate of ATP

328 hydrolysis was calculated from the linear change in A360nm, with correction for MESG conversion to

329 2-amino-6-mercapto-7-methylpurine in absence of Ecm16 protein. The effect of DNA on ATP

330 hydrolysis was studied by adding $2.5 \mu \mathrm{M} 32-$ mer double or single-stranded DNA (containing single

331 echinomycin binding site), $2.5 \mu \mathrm{M}$ echinomycin antibiotic to the assay mixture.

\section{Acknowledgements}

This work was supported by NIH RISE R25GM061222 (A.E.) and the University of Texas System STARs Award (C.-Y.K.).

\section{Author Contributions}

P.M. and C.-Y.K. conceived and supervised the project. P.G. conducted ATP hydrolysis and EMSA measurements. A.E. performed bacterial growth and microscopy studies. P.G., A.E., P.M. and C.-Y.K. wrote the manuscript.

\section{Conflict of Interest Disclosure}

The authors declare no conflict of interests. 


\section{References}

353 1. Ogawara H. 2019. Comparison of Antibiotic Resistance Mechanisms in Antibiotic-Producing and Pathogenic Bacteria. Molecules 24.

2. Wencewicz TA. 2019. Crossroads of Antibiotic Resistance and Biosynthesis. J Mol Biol 431:3370-3399.

3. Walker MS, Walker JB. 1970. Streptomycin biosynthesis and metabolism. Enzymatic phosphorylation of dihydrostreptobiosamine moieties of dihydro-streptomycin-(streptidino) phosphate and dihydrostreptomycin by Streptomyces extracts. J Biol Chem 245:6683-9.

4. Ogawara H. 1981. Antibiotic resistance in pathogenic and producing bacteria, with special reference to beta-lactam antibiotics. Microbiol Rev 45:591-619.

5. Benveniste R, Davies J. 1973. Aminoglycoside antibiotic-inactivating enzymes in actinomycetes similar to those present in clinical isolates of antibiotic-resistant bacteria. Proc Natl Acad Sci U S A 70:2276-80.

6. Martinez JL. 2018. Ecology and Evolution of Chromosomal Gene Transfer between Environmental Microorganisms and Pathogens. Microbiol Spectr 6.

7. de Lima Procópio RE, da Silva IR, Martins MK, de Azevedo JL, de Araújo JM. 2012. Antibiotics produced by Streptomyces. The Brazilian Journal of Infectious Diseases 16:466-471.

8. Waring MJ. 1992. Echinomycin. Pathol Biol (Paris) 40:1022-34.

9. Chen H, Patel DJ. 1995. Solution Structure of a Quinomycin Bisintercalator-DNA Complex. Journal of Molecular Biology 246:164-179.

10. Dawson S, Malkinson JP, Paumier D, Searcey M. 2007. Bisintercalator natural products with potential therapeutic applications: isolation, structure determination, synthetic and biological studies. Nat Prod Rep 24:109-26.

11. Dell A, Williams DH, Morris HR, Smith GA, Feeney J, Roberts GC. 1975. Structure revision of the antibiotic echinomycin. J Am Chem Soc 97:2497-502.

12. Chen C, Chen X, Ren B, Guo H, Abdel-Mageed WM, Liu X, Song F, Zhang L. 2021. Characterization of Streptomyces sp. LS462 with high productivity of echinomycin, a potent anti-tuberculosis and synergistic antifungal antibiotic. J Ind Microbiol Biotechnol doi:10.1093/jimb/kuab079.

13. Dolma S, Lessnick SL, Hahn WC, Stockwell BR. 2003. Identification of genotype-selective antitumor agents using synthetic lethal chemical screening in engineered human tumor cells. Cancer Cell 3:285-96.

14. Sato K, Niinomi Y, Katagiri K, Matsukage A, Minagawa T. 1969. Prevention of phage multiplication by quinomycin A. Biochim Biophys Acta 174:230-8.

15. Carter HE, Schaffner CP, Gottlieb D. 1954. Levomycin. I. Isolation and chemical studies. Arch Biochem Biophys 53:282-93.

16. Yoshida T, Katagiri K, Yokozawa S. 1961. Studies on quinoxaline antibiotics. II. Isolation and properties of quinomycins A, B and C. J Antibiot (Tokyo) 14:330-4.

17. Foster BJ, Clagett-Carr K, Shoemaker DD, Suffness M, Plowman J, Trissel LA, Grieshaber CK, LeylandJones B. 1985. Echinomycin: the first bifunctional intercalating agent in clinical trials. Invest New Drugs 3:403-10.

18. Fernández J, Marín L, Álvarez-Alonso R, Redondo S, Carvajal J, Villamizar G, Villar JC, Lombó F. 2014. Biosynthetic Modularity Rules in the Bisintercalator Family of Antitumor Compounds. Marine Drugs 12.

19. Kinashi H. 2011. Giant linear plasmids in Streptomyces: a treasure trove of antibiotic biosynthetic clusters. J Antibiot (Tokyo) 64:19-25.

20. Kinashi H, Shimaji M, Sakai A. 1987. Giant linear plasmids in Streptomyces which code for antibiotic biosynthesis genes. Nature 328:454-6.

21. Watanabe K, Hotta K, Praseuth AP, Koketsu K, Migita A, Boddy CN, Wang CC, Oguri H, Oikawa H. 2006. Total biosynthesis of antitumor nonribosomal peptides in Escherichia coli. Nat Chem Biol 2:423-8.

22. Furuya K, Hutchinson CR. 1998. The DrrC protein of Streptomyces peucetius, a UvrA-like protein, is a DNA-binding protein whose gene is induced by daunorubicin. FEMS Microbiol Lett 168:243-9. 
23. Keller U, Lang M, Crnovcic I, Pfennig F, Schauwecker F. 2010. The actinomycin biosynthetic gene cluster of Streptomyces chrysomallus: a genetic hall of mirrors for synthesis of a molecule with mirror symmetry. Journal of bacteriology 192:2583-2595.

24. Zhang C, Kong L, Liu Q, Lei X, Zhu T, Yin J, Lin B, Deng Z, You D. 2013. In Vitro Characterization of Echinomycin Biosynthesis: Formation and Hydroxylation of L-Tryptophanyl-S-Enzyme and Oxidation of (2S,3S) $\beta$-Hydroxytryptophan. PLOS ONE 8:e56772.

25. Praseuth AP, Wang CC, Watanabe K, Hotta K, Oguri H, Oikawa H. 2008. Complete sequence of biosynthetic gene cluster responsible for producing triostin $A$ and evaluation of quinomycin-type antibiotics from Streptomyces triostinicus. Biotechnol Prog 24:1226-31.

26. Moolenaar GF, Monaco V, van der Marel GA, van Boom JH, Visse R, Goosen N. 2000. The effect of the DNA flanking the lesion on formation of the UvrB-DNA preincision complex. Mechanism for the UvrAmediated loading of UvrB onto a DNA damaged site. J Biol Chem 275:8038-43.

27. Prija F, Prasad R. 2017. DrrC protein of Streptomyces peucetius removes daunorubicin from intercalated dnrl promoter. Microbiological Research 202:30-35.

28. Sancar A, Rupp WD. 1983. A novel repair enzyme: UVRABC excision nuclease of Escherichia coli cuts a DNA strand on both sides of the damaged region. Cell 33:249-60.

29. Setlow RB, Carrier WL. 1964. THE DISAPPEARANCE OF THYMINE DIMERS FROM DNA: AN ERRORCORRECTING MECHANISM. Proc Natl Acad Sci U S A 51:226-31.

30. Thomas DC, Kunkel TA, Casna NJ, Ford JP, Sancar A. 1986. Activities and incision patterns of ABC excinuclease on modified DNA containing single-base mismatches and extrahelical bases. J Biol Chem 261:14496-505.

31. Nazimiec M, Grossman L, Tang MS. 1992. A comparison of the rates of reaction and function of UVRB in UVRABC- and UVRAB-mediated anthramycin-N2-guanine-DNA repair. J Biol Chem 267:24716-24.

32. Delagoutte E, Fuchs RP, Bertrand-Burggraf E. 2002. The isomerization of the UvrB-DNA preincision complex couples the UvrB and UvrC activities. J Mol Biol 320:73-84.

33. DellaVecchia MJ, Croteau DL, Skorvaga M, Dezhurov SV, Lavrik OI, Van Houten B. 2004. Analyzing the hand off of DNA from UvrA to UvrB utilizing DNA-protein photoaffinity labeling. J Biol Chem 279:4524556.

34. Gunz D, Hess MT, Naegeli H. 1996. Recognition of DNA adducts by human nucleotide excision repair. Evidence for a thermodynamic probing mechanism. J Biol Chem 271:25089-98.

35. Krugh TR, Graves DE, Stone MP. 1989. Two-dimensional NMR studies on the anthramycin-d(ATGCAT)2 adduct. Biochemistry 28:9988-9994.

36. Gomez-Pinto I, Cubero E, Kalko SG, Monaco V, van der Marel G, van Boom JH, Orozco M, Gonzalez C. 2004. Effect of bulky lesions on DNA: solution structure of a DNA duplex containing a cholesterol adduct. J Biol Chem 279:24552-60.

37. Pakotiprapha D, Liu Y, Verdine GL, Jeruzalmi D. 2009. A structural model for the damage-sensing complex in bacterial nucleotide excision repair. J Biol Chem 284:12837-44.

38. Jaciuk M, Nowak E, Skowronek K, Tanska A, Nowotny M. 2011. Structure of UvrA nucleotide excision repair protein in complex with modified DNA. Nat Struct Mol Biol 18:191-7.

39. Pakotiprapha D, Inuzuka Y, Bowman BR, Moolenaar GF, Goosen N, Jeruzalmi D, Verdine GL. 2008. Crystal structure of Bacillus stearothermophilus UvrA provides insight into ATP-modulated dimerization, UvrB interaction, and DNA binding. Mol Cell 29:122-33.

40. Timmins J, Gordon E, Caria S, Leonard G, Acajjaoui S, Kuo M-S, Monchois V, McSweeney S. 2009. Structural and mutational analyses of Deinococcus radiodurans UvrA2 provide insight into DNA binding and damage recognition by UvrAs. Structure 17:547-558.

41. Husain I, Van Houten B, Thomas DC, Sancar A. 1986. Sequences of Escherichia coli uvrA gene and protein reveal two potential ATP binding sites. J Biol Chem 261:4895-901. 
446

42. Oh EY, Claassen L, Thiagalingam S, Mazur S, Grossman L. 1989. ATPase activity of the UvrA and UvrAB protein complexes of the Escherichia coli UvrABC endonuclease. Nucleic Acids Res 17:4145-59.

43. Stracy M, Jaciuk M, Uphoff S, Kapanidis AN, Nowotny M, Sherratt DJ, Zawadzki P. 2016. Single-molecule imaging of UvrA and UvrB recruitment to DNA lesions in living Escherichia coli. Nature communications 7:12568-12568.

44. Kad NM, Van Houten B. 2012. Dynamics of lesion processing by bacterial nucleotide excision repair proteins. Progress in molecular biology and translational science 110:1-24.

45. Kad NM, Wang H, Kennedy GG, Warshaw DM, Van Houten B. 2010. Collaborative dynamic DNA scanning by nucleotide excision repair proteins investigated by single- molecule imaging of quantum-dot-labeled proteins. Mol Cell 37:702-13.

46. Kraithong T, Hartley S, Jeruzalmi D, Pakotiprapha D. 2021. A Peek Inside the Machines of Bacterial Nucleotide Excision Repair. Int J Mol Sci 22.

47. Marszałkowska M, Bil M, Kreft $九$, Olszewski M. 2013. A new division of bacterial UvrA homologues. BioTechnologia 94:54-56.

48. Zhang C, Kong L, Liu Q, Lei X, Zhu T, Yin J, Lin B, Deng Z, You D. 2013. In vitro characterization of echinomycin biosynthesis: formation and hydroxylation of L-tryptophanyl-S-enzyme and oxidation of (2S,3S) beta-hydroxytryptophan. PLoS One 8:e56772.

49. Liu Y, Zhou J, Omelchenko MV, Beliaev AS, Venkateswaran A, Stair J, Wu L, Thompson DK, Xu D, Rogozin IB, Gaidamakova EK, Zhai M, Makarova KS, Koonin EV, Daly MJ. 2003. Transcriptome dynamics of Deinococcus radiodurans recovering from ionizing radiation. Proc Natl Acad Sci U S A 100:4191-6.

50. Tanaka M, Narumi I, Funayama T, Kikuchi M, Watanabe H, Matsunaga T, Nikaido O, Yamamoto K. 2005. Characterization of pathways dependent on the uvsE, uvrA1, or uvrA2 gene product for UV resistance in Deinococcus radiodurans. Journal of bacteriology 187:3693-3697.

51. Shen $\mathrm{CH}$, Chiang YC, Hsu CH, Yang MK. 2007. Identification and characterization of two uvrA genes of Xanthomonas axonopodis pathovar citri. Mol Genet Genomics 277:149-60.

52. Tark M, Tover A, Koorits L, Tegova R, Kivisaar M. 2008. Dual role of NER in mutagenesis in Pseudomonas putida. DNA Repair (Amst) 7:20-30.

53. Adler HI, Hardigree AA. 1965. Growth and Division of Filamentous Forms of Escherichia coli. J Bacteriol 90:223-6.

54. Kantor GJ, Deering RA. 1966. Ultraviolet radiation studies of filamentous Escherichia coli B. J Bacteriol 92:1062-9.

55. Suzuki H, Pangborn J, Kilgore WW. 1967. Filamentous cells of Escherichia coli formed in the presence of mitomycin. J Bacteriol 93:683-8.

56. Miller C, Thomsen LE, Gaggero C, Mosseri R, Ingmer H, Cohen SN. 2004. SOS response induction by betalactams and bacterial defense against antibiotic lethality. Science 305:1629-31.

57. Rossi F, Khanduja JS, Bortoluzzi A, Houghton J, Sander P, Güthlein C, Davis EO, Springer B, Böttger EC, Relini A. 2011. The biological and structural characterization of Mycobacterium tuberculosis UvrA provides novel insights into its mechanism of action. Nucleic acids research 39:7316-7328.

58. Seeberg E, Steinum A-L. 1982. Purification and properties of the uvrA protein from Escherichia coli. Proceedings of the National Academy of Sciences 79:988-992.

59. Van Dyke MM, Dervan PB. 1984. Echinomycin binding sites on DNA. Science 225:1122-7.

60. Thomas DC, Levy M, Sancar A. 1985. Amplification and purification of UvrA, UvrB, and UvrC proteins of Escherichia coli. J Biol Chem 260:9875-83.

61. Thiagalingam S, Grossman L. 1993. The multiple roles for ATP in the Escherichia coli UvrABC endonuclease-catalyzed incision reaction. J Biol Chem 268:18382-9.

62. Thiagalingam S, Grossman L. 1991. Both ATPase sites of Escherichia coli UvrA have functional roles in nucleotide excision repair. J Biol Chem 266:11395-403. 
63. Kraithong T, Channgam K, Itsathitphaisarn O, Tiensuwan M, Jeruzalmi D, Pakotiprapha D. 2017. Movement of the beta-hairpin in the third zinc-binding module of UvrA is required for DNA damage recognition. DNA Repair (Amst) 51:60-69.

64. Pakotiprapha D, Samuels M, Shen K, Hu JH, Jeruzalmi D. 2012. Structure and mechanism of the UvrAUvrB DNA damage sensor. Nat Struct Mol Biol 19:291-8.

65. Kisker C, Kuper J, Van Houten B. 2013. Prokaryotic nucleotide excision repair. Cold Spring Harbor perspectives in biology 5:a012591-a012591.

66. Orren DK, Sancar A. 1989. The (A)BC excinuclease of Escherichia coli has only the UvrB and UvrC subunits in the incision complex. Proceedings of the National Academy of Sciences 86:5237-5241.

67. Yeung AT, Mattes WB, Grossman L. 1986. Protein complexes formed during the incision reaction catalyzed by the Escherichia coli UvrABC endonuclease. Nucleic Acids Res 14:2567-82.

68. Caron PR, Kushner SR, Grossman L. 1985. Involvement of helicase II (uvrD gene product) and DNA polymerase I in excision mediated by the uvrABC protein complex. Proceedings of the National Academy of Sciences of the United States of America 82:4925-4929.

69. Baba T, Ara T, Hasegawa M, Takai Y, Okumura Y, Baba M, Datsenko KA, Tomita M, Wanner BL, Mori H. 2006. Construction of Escherichia coli K-12 in-frame, single-gene knockout mutants: the Keio collection. Molecular systems biology 2:2006.0008-2006.0008.

70. Boyce RP, Howard-Flanders P. 2003. Release of ultraviolet light-induced thymine dimers from DNA in E. coli K-12. 1964. DNA Repair (Amst) 2:1280-7.

71. Springall L, Hughes CD, Simons M, Azinas S, Van Houten B, Kad NM. 2018. Recruitment of UvrBC complexes to UV-induced damage in the absence of UvrA increases cell survival. Nucleic acids research 46:1256-1265.

72. Mazon G, Philippin G, Cadet J, Gasparutto D, Fuchs RP. 2009. The alkyltransferase-like ybaZ gene product enhances nucleotide excision repair of $\mathrm{O}(6)$-alkylguanine adducts in E. coli. DNA Repair (Amst) 8:697-703.

73. Tubbs JL, Latypov V, Kanugula S, Butt A, Melikishvili M, Kraehenbuehl R, Fleck O, Marriott A, Watson AJ, Verbeek B, McGown G, Thorncroft M, Santibanez-Koref MF, Millington C, Arvai AS, Kroeger MD, Peterson LA, Williams DM, Fried MG, Margison GP, Pegg AE, Tainer JA. 2009. Flipping of alkylated DNA damage bridges base and nucleotide excision repair. Nature 459:808-13.

74. Yang W. 2011. Surviving the sun: repair and bypass of DNA UV lesions. Protein Sci 20:1781-9.

75. Ducret A, Quardokus EM, Brun YV. 2016. MicrobeJ, a tool for high throughput bacterial cell detection and quantitative analysis. Nat Microbiol 1:16077.

76. Schneider CA, Rasband WS, Eliceiri KW. 2012. NIH Image to ImageJ: 25 years of image analysis. Nature Methods 9:671.

77. Schindelin J, Arganda-Carreras I, Frise E, Kaynig V, Longair M, Pietzsch T, Preibisch S, Rueden C, Saalfeld S, Schmid B, Tinevez J-Y, White DJ, Hartenstein V, Eliceiri K, Tomancak P, Cardona A. 2012. Fiji: an opensource platform for biological-image analysis. Nature Methods 9:676.

78. Ducret A, Quardokus EM, Brun YV. 2016. MicrobeJ, a tool for high throughput bacterial cell detection and quantitative analysis. Nature microbiology 1:1-7.

79. Schneider CA, Rasband WS, Eliceiri KW. 2012. NIH Image to ImageJ: 25 years of image analysis. Nature methods 9:671-675. 
Figure 1

A

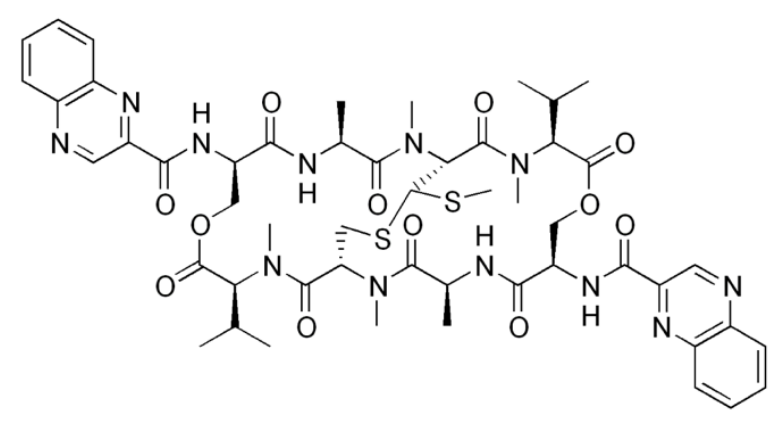

C

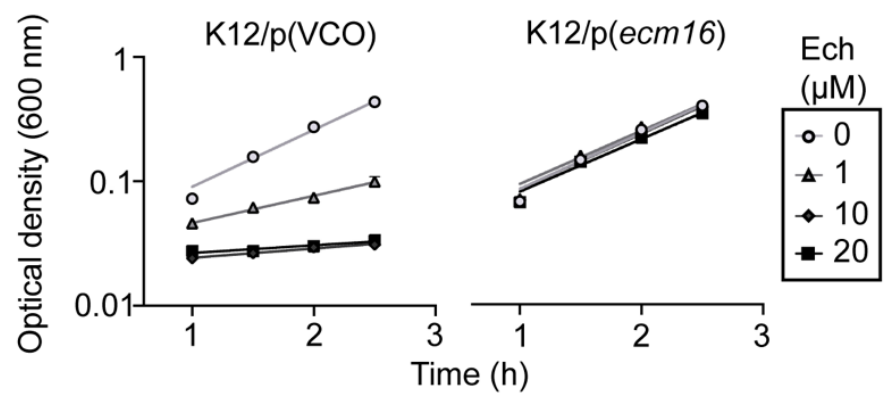

B

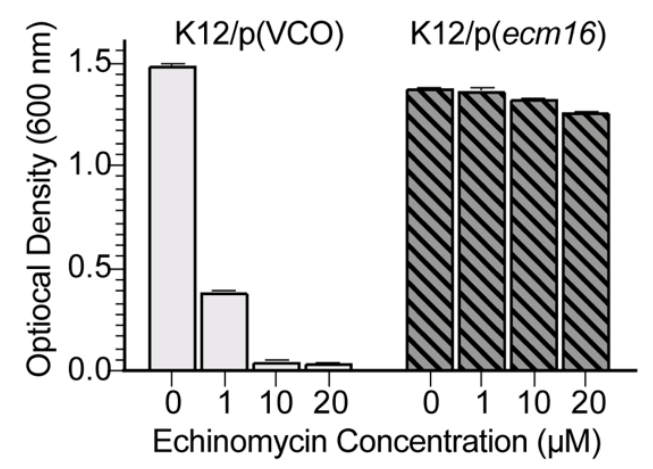

Figure 1. Expression of ecm16 gives resistance against echinomycin. (A) Structure of echinomycin. (B) Optical density after 6 hours. Exposure to echinomycin results in reduction of $E$. coli growth in liquid media. Maximum optical densities were determined after $6 \mathrm{~h}$ exposure to echinomycin concentrations ranging from $1 \mu \mathrm{M}$ to $20 \mu \mathrm{M}$. Echinomycin was added at time zero to cultures at $0.2 \mathrm{OD}_{600 \mathrm{~nm}}$. E. coli K12 strains with pBAD vector-control-only (VCO) or pBAD-ecm16 ( $\mathrm{p}(\mathrm{ecm} 16)$ were used for comparison. Error bars represent standard error for duplicate replicates of one trial, analysis is representative of three independent trials. (C) Exponential state growth curves of K12/pVCO and K12/p(ecm16) on a semilogarithmic plot. Cultures were grown in rich media (LB) supplemented with echinomycin (0 to $20 \mu \mathrm{M})$ and arabinose inducer (0.2\%). Error bars represent standard error of the mean (SEM) of duplicate replicates. All results shown are representative of three independent replicates. 


\section{Figure 2}

A
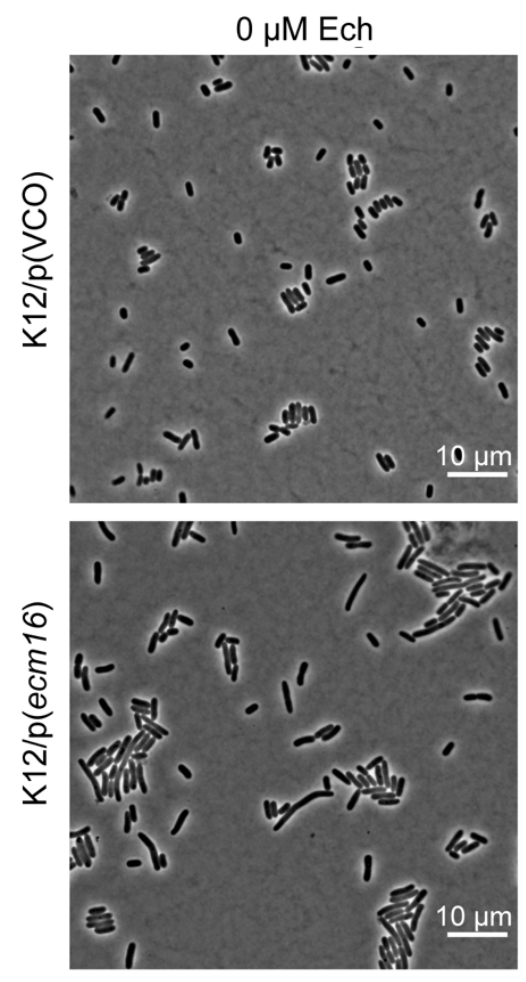

B
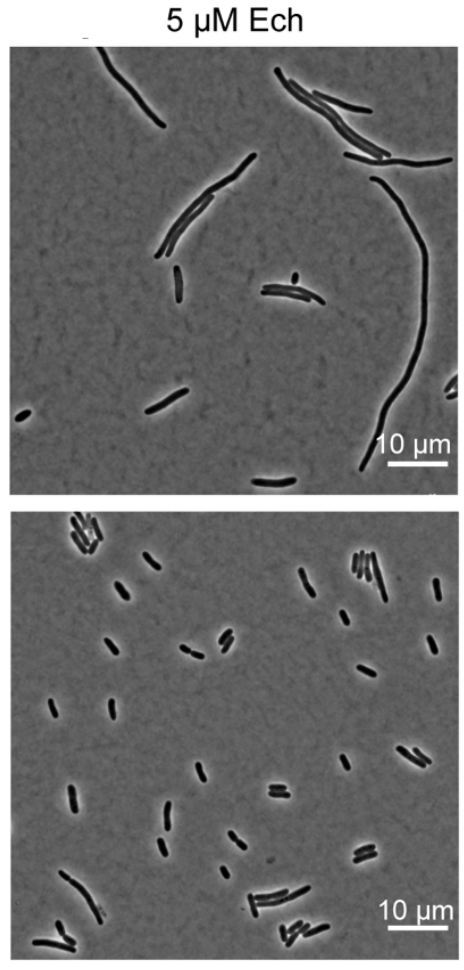

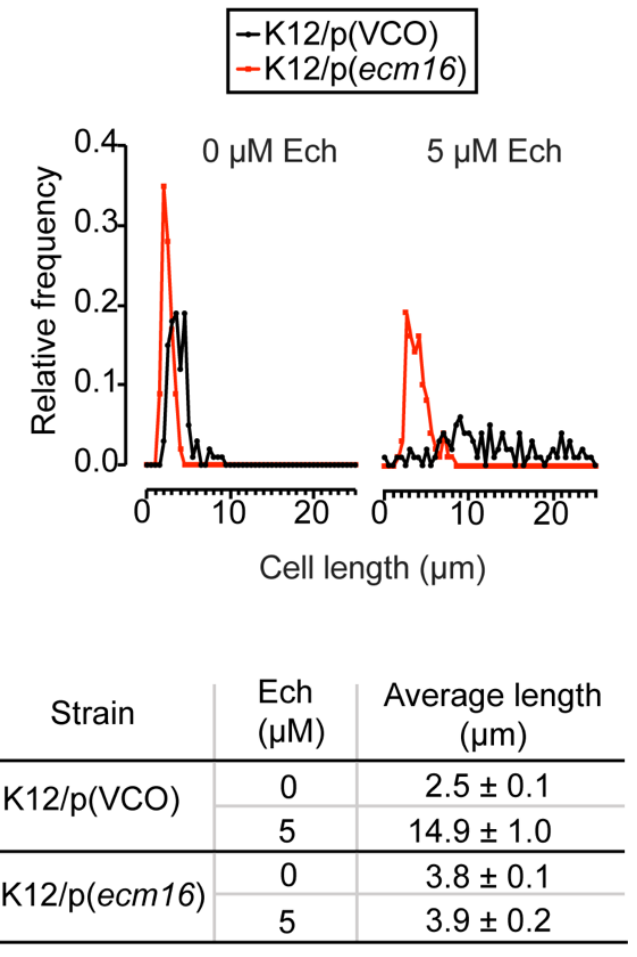

Figure 2. E. coli cells expressing ecm16 do not filament after echinomycin treatment. (A) Phase contrast microscopy of strains $\mathrm{K} 12 / \mathrm{p}$ (VCO) (top panels) and $\mathrm{K} 12 / \mathrm{p}(\mathrm{ecm} 16)$ (bottom panels) grown in the presence of inducer (arabinose $0.2 \%$ ) supplemented with or without $5 \mu \mathrm{M}$ echinomycin (ech). Cells were grown in the presence of echinomycin for $5 \mathrm{~h}$ and subsequently spotted on $1 \%$ agarose minimal media pads for imaging. Scale bar $=10 \mu \mathrm{m}$. (B) Cell size distribution and average cell length and standard error for 100 cells per condition are shown. $7 \%$ of cells displayed cell lengths over $25 \mu \mathrm{m}$ (not included in plot). Cell lengths were measured using the software MicrobeJ. Representatives of three independent replicates are plotted. Cell lengths were binned in $0.5 \mu \mathrm{m}$ increments and plotted using Prism. 
Figure 3

A

(a)

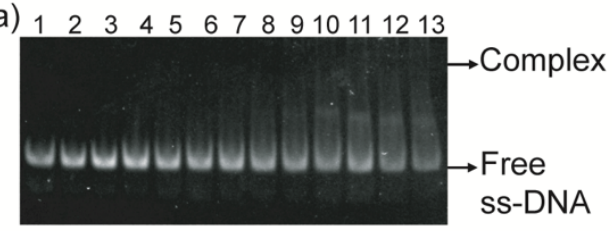

(b) 123345678910111213

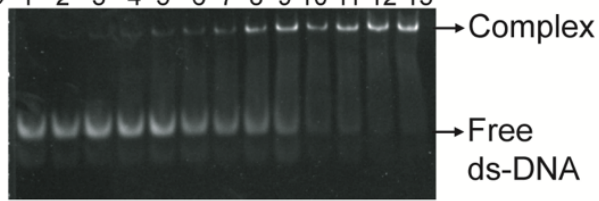

(c) $12 \begin{array}{llllllllll}1 & 2 & 4 & 4 & 6 & 6 & 8 & 9 & 1011 & 1213\end{array}$

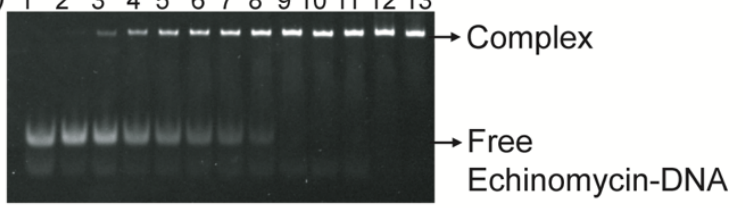

B

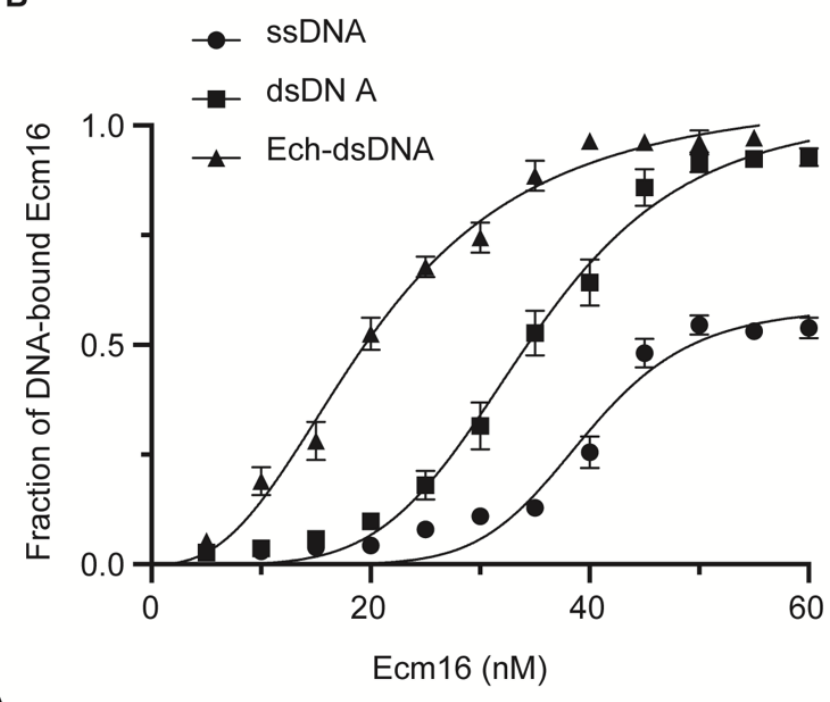

C

DNA Sequence Independent Binding Mode of Ecm16

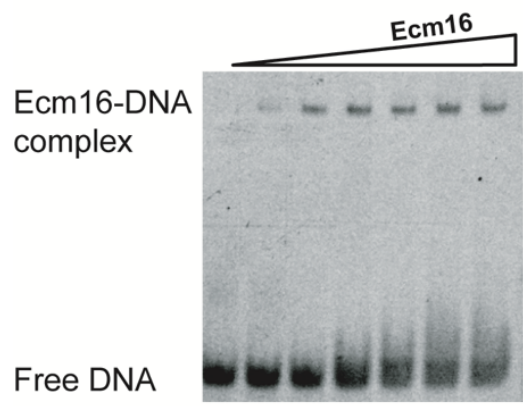

GC content - $100 \%$

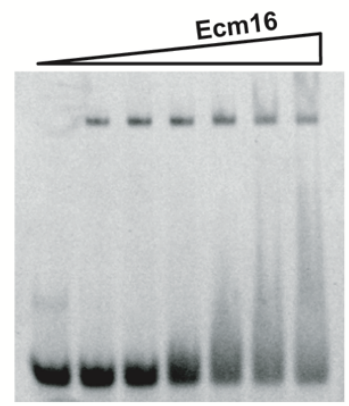

AT content - $100 \%$

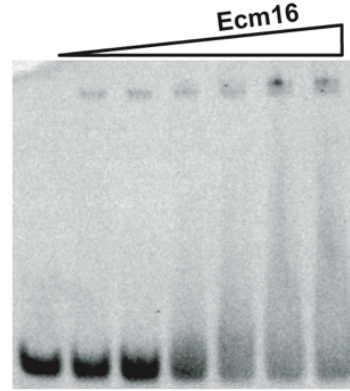

GC/AT content - $75 \% / 25 \%$

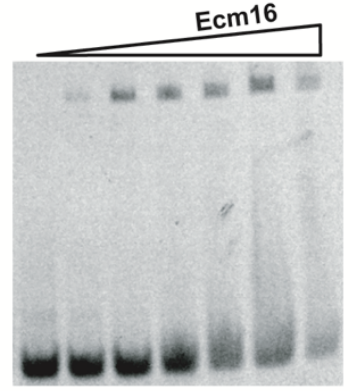

GC/AT content $50 \% / 50 \%$

Figure 3. DNA binding activity of Ecm16. (A) Reaction mixtures contained $0.25 \mathrm{nM}$ DNA substrate in the absence (lane 1) or presence of 5 to $60 \mathrm{nM}$ Ecm16 with increment of $5 \mathrm{nM}$ (lanes 2-13), (a) ssDNA; (b) dsDNA; (c) Echinomycin-DNA. (B) Fraction of ssDNA (panel (a)), dsDNA (panel (b)), Echinomycin-DNA (panel (c)) bound to Ecm16 is plotted against the indicated amounts of Ecm16. ssDNA (filled circles); dsDNA (filled squares); Echinomycin-DNA (filled triangles). Each point on the curves represents the mean of three separate experiments. (C) DNA binding activity of Ecm16 in presence of $100 \%$ GC and AT, $75 \% / 25 \%$ and $50 \% / 50 \%$ GC/AT composition 0.25 nM DNA substrates in the absence (lane 1 ) or presence of 5 to $30 \mathrm{nM} \mathrm{Ecm} 16$ with increment of $5 \mathrm{nM}$ (lanes 2-7). 
Figure 4

A

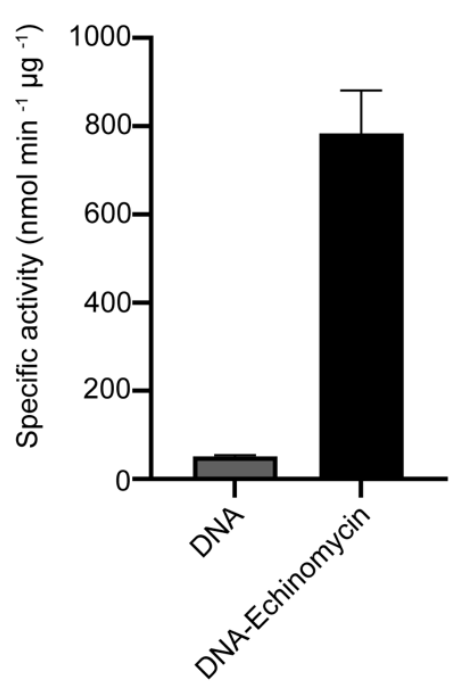

\begin{tabular}{|c|c|}
\hline Substrate & Specific activity $\left(\mathrm{nmol} \mathrm{min}^{-1} \mu \mathrm{g}^{-1}\right)$ \\
\hline- & $4.53 \pm 0.39$ \\
\hline DNA & $51.47 \pm 3.17$ \\
\hline DNA-Echinomycin & $783.84 \pm 97.56$ \\
\hline
\end{tabular}

B

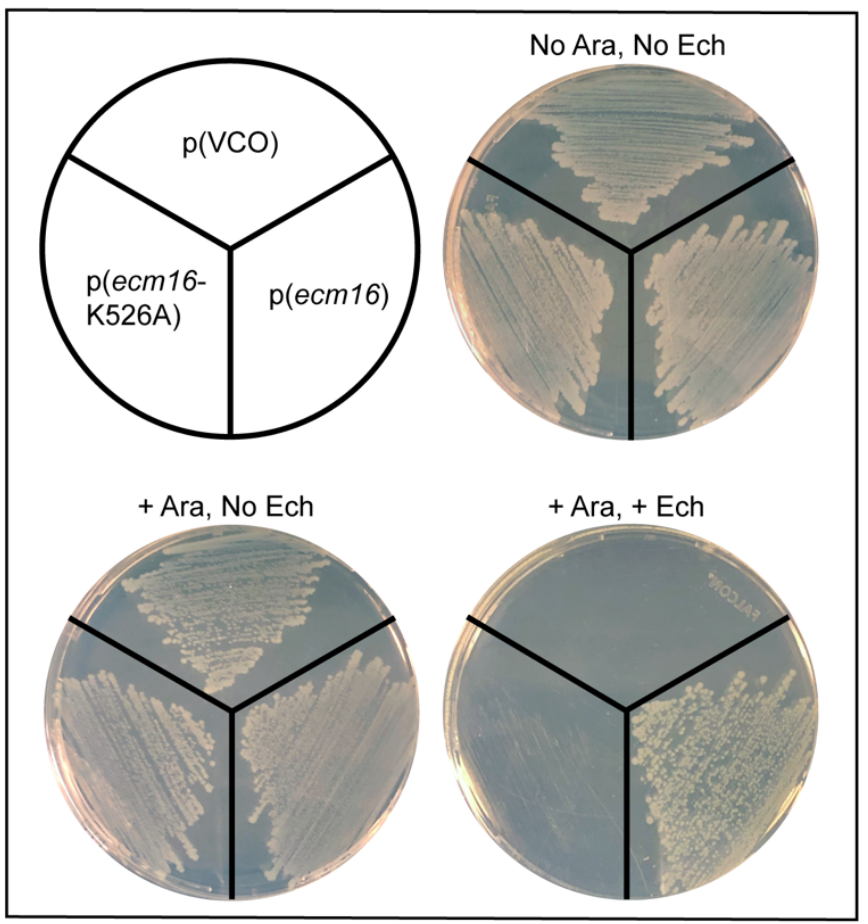

Figure 4. (A) Specific activity of $0.2 \mu \mathrm{M}$ purified Ecm16 in the presence or absence of $1 \mu \mathrm{M}$ DNA and DNAechinomycin substrates. Error bars represent standard error of three independent experiments. The reaction mixture contained 2-amino-6-mercapto-7-methylpurine (MESG) and purine nucleoside phosphorylase, $1 \mathrm{mM}$ ATP and $10 \mathrm{mM} \mathrm{MgCl}_{2}$. A phosphate standard was measured to calibrate the UV absorbance signal to the amount of inorganic phosphate release. (B) Streak plates containing E. coli cultures containing a plasmid with WT ecm16 ( $\mathrm{p}($ emc16)), ecm16 ATP-binding variant ( $\mathrm{p}(\mathrm{emc16}-\mathrm{K} 526 \mathrm{~A})$ ), or vector control $(p(V C O))$. Cultures were grown overnight and normalized to $0.5 \mathrm{OD}_{600}$ before streaking on LB ampicillin plates containing $0.2 \%$ arabinose or $1 \mu \mathrm{M}$ echinomycin (with $0.2 \%$ arabinose) and were incubated at $37^{\circ} \mathrm{C}$ overnight. Plates are representative of 3 independent trials. 
Figure 5

A

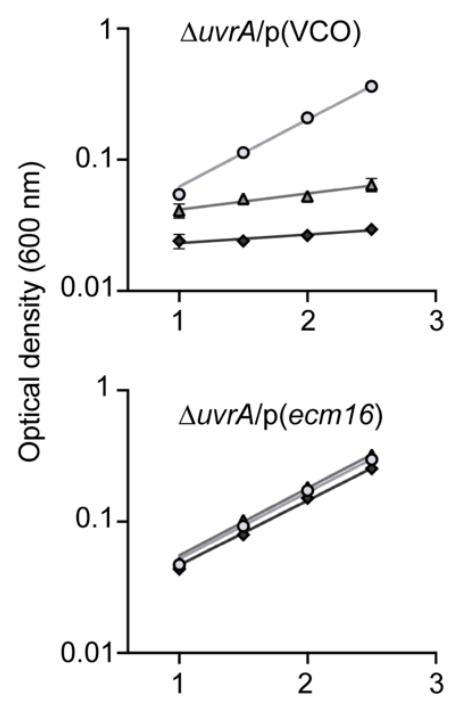

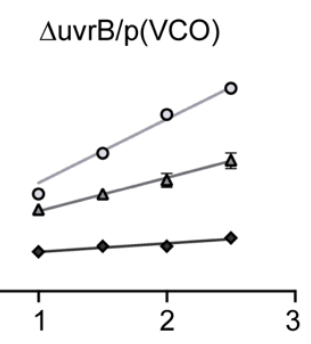

$\Delta u v r C / p($ VCO $)$

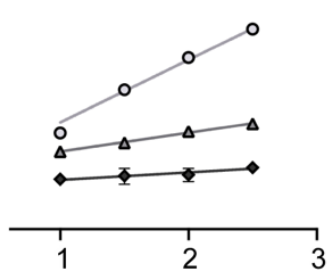

$\Delta u v r B / p(e c m 16)$
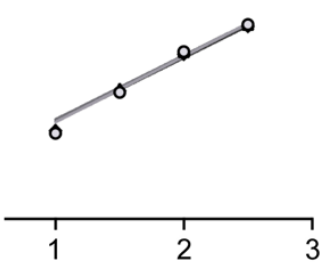

Time (hours)

$\Delta u v r C / p(e c m 16)$

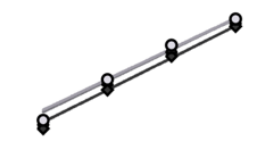

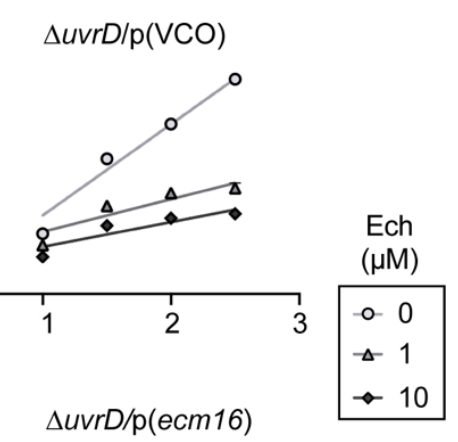

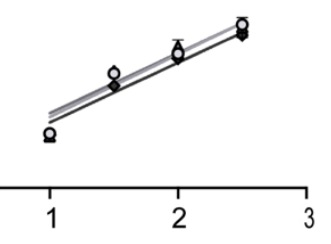

B
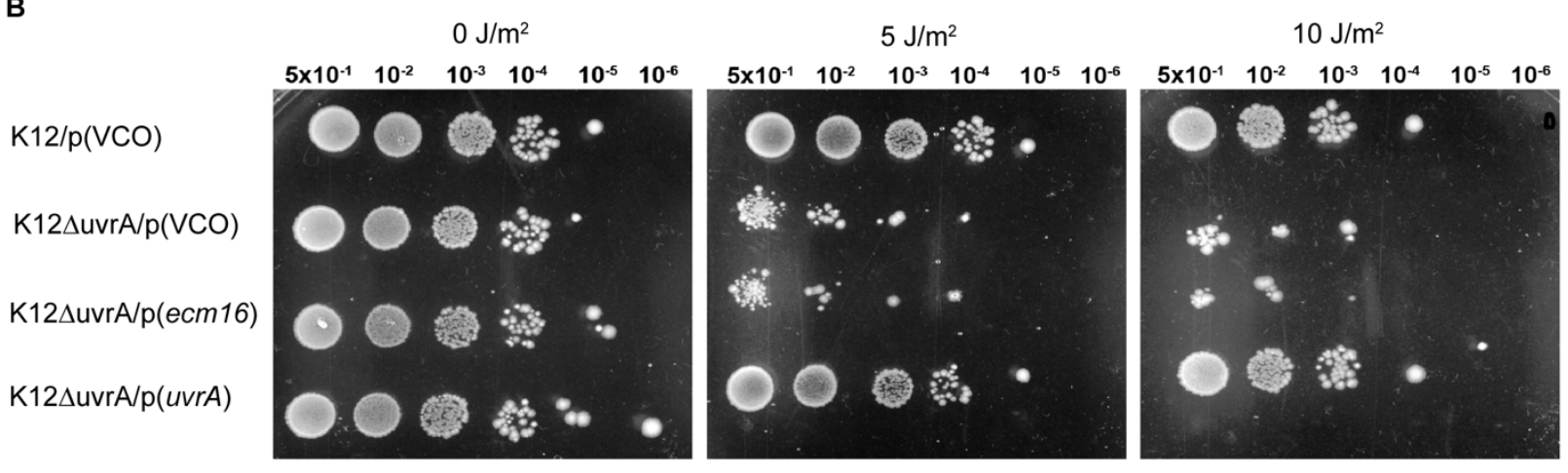

Figure 5. Ecm16 is not associated with classic NER function. (A) Exponential state growth curves $(\mathrm{n}=$ 3 ) of $E$. coli $\mathrm{K} 12$ strains with different components of the native nucleotide excision repair system (NER) knocked out ( $\triangle u v r A, \Delta u v r B, \Delta u v r C$ or $\Delta u v r D)$ and carrying vector-control-only or vector encoding ecm 16 . Cultures $(2 \mathrm{~mL})$ were set to $\mathrm{OD}_{600 \mathrm{~nm}} \sim 0.2$ in rich media (LB) supplemented with the inducer $(0.2 \%$ arabinose) and varying concentrations of echinomycin $(0-10 \mu \mathrm{M})$. Growth was monitored by measuring the absorbance at $600 \mathrm{~nm}$ every 30 minutes. E. coli K12 NER knockouts show similar patterns of resistance to echinomycin in the presence of inducer for the expression of ecm16. Results are shown for exponential growth phase with exponential trend line, error bars represent SEM of duplicate replicates. All results shown are representative of three independent replicates. (B) Colony Forming Unit (CFU) assays after UV radiation. $5 \mu \mathrm{L}$ of cultures grown to $\mathrm{OD}_{600 \mathrm{~nm}} \sim 0.2$ were serial diluted (dilution factor $=5 \times 10^{-1}$ to $10^{-6}$ ) and spotted on LB plates supplemented with $0.2 \%$ arabinose. Cultures included the following strains: control sample (top row) are wild-type cells with vector-control-only, test samples (middle $2^{\text {nd }}$ and $3^{\text {rd }}$ rows) are strains with the native $E$. coli's uvrA gene knocked out and with vector-control-only or vector encoding ecm16, complementation control strain (bottom row) encodes $E$. coli's native uvrA gene in the same pBAD vector. Freshly spotted plates were exposed to UV radiation and then incubated at $37^{\circ} \mathrm{C}$ for $18 \mathrm{~h}$ prior to imaging. The data shown are a representative of three independent replicates. 